\title{
Maintaining Ethnic Boundary : The Ethnogenesis of Madhesi identity in Nepal Tarai
}

- Nirodh Pandey*

\begin{abstract}
This article attempts to illuminate on the processes wherein diverse groups of Madhesi people of the central Tarai have been ethnicized to form a shared identity in the specific historical and socio-political context of Nepal. Drawing on the perceptions and subjective experiences of Madhesi individuals in terms of their identity, it is argued that Madhesi identity has come into being and maintained through the practices of boundary maintenance that encompasses relational processes of inclusion and exclusion. Madhesi people have re(asserted) their cultural contrast to the Pahadis and claim political autonomy of the Tarai territory where they belong for making ethnic distinction and maintaining group boundary.
\end{abstract}

Keywords: Ethnic boundary, Madhesi identity, ethnogenesis, culture, ethno-territoriality

\section{Introduction}

The processes of making or asserting identity by different ethnic groups in Nepal have remained an important subject matter in anthropological or ethnographic studies. While most of the anthropologists have empirically explored and examined the identity issues of indigenous and ethnic groups of the high land (hill and mountain) (Gellner, Pfaff-Czarnecka

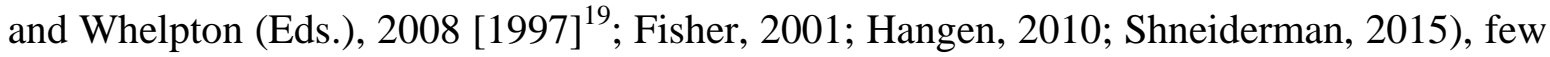
have been concerned on the identity making of low land indigenous/ ethnic groups such as Tharu (Guneratne, 2002) and caste Madhesis (Bhattarai, 2000). As (Levine (1987) and Holmberg (1996 [1989]) have reminded, these accounts have a shared assertion that the making or remaking of identity has to be seen as an ongoing process of response of particular ethnic group to the formation of Nepali nation-state over time. Meant as a contribution to this literature, this article attempts to illuminate on the processes wherein diverse groups of Madhesi people ${ }^{20}$ of the central Tarai have been ethnicized to form a

\footnotetext{
* Mr. Pandey is an Assistant Professor of Anthropology, Patan Multiple Campus, TU, Nepal

${ }^{19}$ However, Claire Burkert and Christian McDonaugh have discussed about Maithil identity in Janakpur and land issues of Tharu in Dang respectively.

${ }^{20}$ Because of the complex composition of population with great diversity in terms of caste/ethnicity, culture, language, history of settlement and so on, defining Madhesi people has been remained a contentious and
} 
shared identity in the specific historical socio-political context of Nepal. Putting differently, to examine the processes of ethnogenesis - the making of Madhesi ethnicity ${ }^{21}$ - in Nepal Tarai particularly focusing on the post-1990 socio-political scenario and more particularly since the Madhes Uprising of $2007^{22}$ is the major focus of this article. In particular, it explores and examines how Madhesi ethnic boundaries have become fortified at this particular historical juncture, what kind of processes were at work and how have Madhesis been strategically employing their socio-cultural differences and belonging to a particular territory, the Tarai as a political resource in the changing socio-political context. As suggested by Shneiderman (2012), this article seeks the understanding of subjective content of Madhesi ethnicity or Madhesi ethnic consciousness and primarily focuses on the actions and practices adopted by Madhesi people for shaping and re-shaping their selfidentification.

This article is based on the data generated from ethnographic fieldwork that was conducted in Birganj in March 2018. Narratives of Madhesi individuals, especially their perceptions and subjective experiences in terms of their identity remained my primary ethnographic sites. I employed unstructured method, especially informal conversation with research participants in their own local settings. Secondary data also have been used wherever necessary.

In what follows I will begin with a brief discussion of the theoretical context of the study. Then I will examine how Madhesis have re(asserted) their cultural contrast to the Pahadis for maintaining the ethnic boundary. This follows the discussion on expanding and contracting nature of Madhesi ethnic boundary and Madhesis' claim of ethno-territoriality as a strategy to seek political autonomy. Finally, I will conclude arguing that Madhesi

controversial task. Scholars have variously portrayed theMadhesi community. For example, Gaige (1975) divided Madhesis into three broad categories: Indigenous groups, groups which have cross-border cultural, linguistic and kinship affiliations, and migrants from the hills. Dahal (2008) has categorized four groupsindigenous ethnic people living in Madhes for generations, people belonging to traditional Hindu caste hierarchy, business persons of Indian origin and Muslims that form a Madhesi community. Hachhethu (2007) has labeled plain's Hindu caste groups, ethnic groups and Muslims as Madhesis. But, for the purpose of this study, only the Hindu caste groups are considered as Madhesis.

${ }^{21}$ In Nepal, Madhesis are not identified as an ethnic group identical to adibasijanjati, indigenous nationalities. Rather, officially they are categorized as caste-origin Tarai groups who have been configured along the four fold Hindu caste structure. However, this study presumes that Madhesi is an ethnic group possessing perceived ethno-regional and cultural distinctions.

${ }^{22} \mathrm{~A}$ twenty one-day long mass movement participated in by Madhesi people irrespective of caste position, gender, class, language and other divisions in January-February 2007 is popularly defined by Madhes Uprising or Madhesi revolt (see Gautam, 2008; Mathema, 2011). It is claimed that Madhes Uprising changed the course of politics by ensuring federalism in Nepal (see Hachhethu, 2007). 
ethnogenesis has been occurring at such a particular historical juncture when the structure and power of the state has entered in the unprecedented course of transition.

\section{Theoretical Context}

The theoretical context of this study is the Barth's (1969) interactional approach of ethnicity. His concept of 'ethnic boundary' offers significant insights to discuss how ethnic distinctions are made and ethnic boundaries are erected. In the study of ethnicity, the concept of boundary has helped us understand the signaling effects of cultural idioms whereby membership in contrasted ethnic groups are made visible and thereby socially effective (Barth, 2000). Departing from the primordial notion that defines ethnicity as inherent and given, Barth established constructivism which "claims that ethnicity is the product of a social process rather than a cultural given, made and remade rather than taken for granted, chosen depending on circumstances rather than ascribed through birth" (Wimmer, 2008, p. 971). That is, according to Barth, ethnic identity is contingent on the circumstances and relative positions of the significant others.

Barth is interested in exploring different processes that seemed to be involved in generating and maintaining ethnic groups (Barth, 1969, p. 10). He asserts that the most important dimension of ethnicity is "the ethnic boundary that defines the group, not the 'cultural stuff' that it encloses” (p. 15). He defines ethnic group as an organizational type, a product of social ascription - self-ascription and ascription by others (p. 13). He asserts, "If a group maintains its identity when members interact with others, this entails criteria for determining membership and ways of signaling membership and exclusion .... The ethnic boundary canalizes social life - it entails a frequently quite complex organization of behavior and social relationships” (Barth, 1969, p. 15).

What will be explained in succession is that the ongoing boundary demarcation and maintenance practices in the Tarai demonstrate how Madhesi people (re)create cultural difference and (re)claim ethno-territoriality for asserting their distinct identity. As Barth (1969) asserts, Madhesi ethnicity is a social construct that is contingent on the relationship to the "other", the Pahadi. However, ethnicization of Madhesis has been going on by (re)enforcing the cultural contrast to the Pahadis. Yet, Madhesis are not static carriers of culture.

\section{Cultural or symbolic markers of Madhesi boundary}

Madhesi culture or the symbols that are the vehicles of Madhesi culture are reproduced in the context of increasing social interface between Madhesi and Pahadi. As the interaction of Madhesis with the Pahadis became extensive and intense in the emerging socio-political context of federalization, certain cultural or symbolic markers that differentiate Madhesis 
from the "others" were reinforced. That is, Madhesis became assertiveof their perceived cultural differentiation at the brink of socio-political transition. A Birganj based TV journalist belonging to the Madhesi community stated:

Irrespective of belonging to different caste groups, Madhesis' cultural world seems to be shared. The common attire, similar linguistic tones despite of different Madhesi dialects such as Maithili, Bhojpuri and Awadhi, perceived common physical appearance, commonalities in the ways of celebration of popular festivals such as Chhath and Holi, common preferences to food and food habits - indeed, 'common ways of life' has brought all the Madhesi groups together to act as a single group. Different Madhesi groups have their caste specific socio-cultural practices seemingly independent from each other. But, when they interact with the Pahadis, all Madhesi groups consider themselves as culturally distinctive. When they feel that the Madhesi community is imposed to cultural and political threats especially from culturally and politically dominant Pahade people, diverse Madhesi groups provoke the cultural commonalities among themselves and instinctively consolidate as one people.

Asserting cultural distinctiveness, a local level political leader of a Madhesi political party belonging to the middle-caste Madhesi group argued:

The Hindutva and the caste system guided by it have been differently practiced by Madhesis and Pahadis even if they possess certain commonalities. Comparatively upper casteMadhesi people seem to be more caste-sensitive in their social interactions especially in marriage and inter-dining than Pahadis. The concepts of purity and pollution seem to be deeply rooted in determining the extents of sociocultural interactions. Even though, Madhesis have been divided into many caste groups, there has been functional interdependence in ritual and cultural practices.

These narratives suggest that there are certain cultural distinctions between Pahadis and Madhesis that are embedded in the caste and religious ideologies. As Bista (1996) argues, in contrast to the liberal Hindu hill people, Madhesi people are orthodox in their beliefs following Hinduism and caste rules as closely as possible to the classical Hindu pattern. In the plains, Hinduism has been affected by interaction with Islam, from which it has adopted practices such as purdha, the keeping of women in a state of seclusion (Gaige, 2009). Although by no means common, inter-caste marriages sometimes take place among hill people; such marriages are considered taboo among the plains people (Gaige, 2009).

While they keep themselves culturally apart from Pahadis, diverse Madhesi groups believe that they possess a shared cultural civilization. The belief in shared culture has enabled 
Madhesis not only for their self-identification but also to represent themselves as a perceivingly typical community from their significant others. Jha (2017 [1993], p. 8) writes that the way of life the Madhesi people have adopted is in many ways different from that of the mountains and the hills; the caste system, language, dress, food habits and housing structure of these people are all distinct. Likewise, Yadav (2011, p. 157) mentions that some of the signs, i.e. attire, housing structures, cultural forms of behavior, language, and most importantly, appearance do highlight the difference of a Madhesi from a Pahadi. This implies that provoking the shared culture Madhesis want to be recognized as culturally different people from Pahadi people. As Hyome (2006) argues, a single element that unites diverse Madhesi groups is the historical, cultural and geographical difference betweenPahadi and Madhesi. Thus, Madhesis' collective identity seems to be founded on a marked opposition between "we" and "others," that is inscribed in culture.

Under certain circumstances, the concept ofrace has been used by Madhesi leaders and activists to explain social inequality and justify political action against a defined racial other - the Pahadi. That is, they have asserted racial identity as an effective political strategy for forming oppositional identity. Though self-identification of Madhesi people as a different race than the politically dominant hill high caste Hindus based on perceived difference in physical appearance is problematic, Madhesis have also sought that the reason behind the backwardness of Madhesi community was the racial discrimination from that of ruling class formed by Pahadi people (see Sah, 2017).

Madhesi people have symbolized certain elements of culture to mark the difference. Dhoti as a shared symbol has been symbolically politicized for defending Madhesi community as a distinct cultural world. Even though new generation Madhesis do not wear Dhoti in their everyday life, they possess a deep-seated sense that it is such a symbol that gives them a distinct identity of being different from Pahadi people. A local cadre of the then Sanghiya Samajbadi Forum asserted:

Earlier Madhesi people used to feel intense humiliation and insult while calling them Dhoti depreciatively. But now, as the Dhoti's actions/ movements became the precursor for federalism, inclusion and social justice in Nepal, they have begun to feel pride and say 'Yes! We are Dhoti'. Labeling them Dhoti now is not so much offensive as it used to be in the past. The people of Nepal now proudly claim themselves as citizens of federal democratic republic because of the actions and stance taken by those once neglected Dhotis at the cost of the sacrifice of their lives. Labeling Madhesi group by Pahade people unduly as denigrating over time became 
a strong shared sense of being Madhesi. Now, the Madhesis acclaim 'speak with pride that we are Madhesi - we are not foreign fugitive but children of soil' ${ }^{23}$.

Symbolically, Dhoti has been used in Nepal as a marker of 'othering' Madhesi population by Pahadi community. Since the recent past, it has been admitted by Madhesi individuals that Dhoti has become a tool that provides socio-cultural cohesion and shared sense of identity among Madhesis at least in the course of their political struggles for recognition. Mukesh Jha (2016) put that a popular Dhoti movement has reinstated the pride of the cultural attire of the people of Madhes; calling Madhesis Dhoti might be a popular racial slur, but it does not offend Madhsis anymore. Dhoti symbolically created the bases for ethnic mobilization as collective meaning was assigned to it and a community was constructed on it. In other words, the politicization of Madhesi culture and symbols formed the bedrock for the mobilization of Madhesi people in the sporadic movements against the government and the Pahadi people. Madhesi peoples' own experience of a cultural difference to Pahadi people is schematized by drawing a Madhesi ethnic boundary. As Barth (1994) revisited his earlier formulation and noted, 'cultural stuff' mattered inMadhesiboundary maintenance to a greater extent. Contrary to Guneratne’s (2002) argument that a system of shared symbols is not a necessary precondition or basis for the development of common ethnic identity, the making of Madhesi identity seems to be built on the reinvented symbol - Dhoti. Madhesi ethnicity seems to be a matter of consciousness based on the constructed cultural commonality to a greater extent. In other words, Madhesis' cultural differentiation from Pahadis seems to be operating in making and maintaining Madhesi boundary. Disguising the broader linguistic and cultural differences among different groups, Madhesis tend to represent themselves as a single and coherent entity referring to the commonalities of cultural symbols such as costumes, linguistic tone and shared history, and most importantly they prefer to bring a discourse to the fore that for being different in cultural practices than that of Pahadi they have been continuously suffering from not only cultural domination but also political exclusion and economic marginalization (see Shah, 2006). Madhesis have been seemingly strategic to seek recognition of their distinct culture by drawing cultural boundaries against Pahadis. As Eriksen (2010) argues, when cultural differences regularly make a difference in interaction between members of groups, the social relationship has an ethnic element. He further adds that cultural differences relate to ethnicity if and only if such differences are made relevant in social interaction. The manipulation of the cultural difference has helped Madhesis to form a ethno-regional movement.

\footnotetext{
${ }^{23} \mathrm{~A}$ proverb in Maithili language - Garv se kahun hum Madhesi chhi, bideshi bhagauda nahi; dhartiputra chhi became very much popular slogan following the Madhesi uprising.
} 
As discussed above, by virtue of cultural contents such as language, customs, festivals, and so on, Madhesis prefer to distinguish themselves from the Pahadis. Shared cultural values and denominators that have created a sense of belonging and affective attachment among them and their cultural distance from "others" have mobilized Madhesis as a collectivity to confront with the state that is largely represented by the dominant "others," the Pahadi. Whether or not its structural boundaries remain intact, the reality of community lies in its members' perceptions of the vitality of its culture (Cohen, 1985). It is revealed that Madhesis have constructed their community symbolically, making it a resource and repository of meaning, and a referent of their identity. They have attempted to define the Madhesi 'nation as a cultural community' (Eriksen, 2010), a community that shares a common ways of life. That is, their efforts are for making the "political use of cultural symbols" (Eriksen, 2010, p. 123-125) for developing their own distinct nation-ness. However, as Guneratne (2002, p. 13) puts, "an ethnic group is not simply a cultural group; it is a cultural group that is self-consciously aware of its culture, a group for whom its culture - or some aspect of it - has become an object and a symbol of its separate identity. Objectively speaking, ethnic consciousness does not require any great degree of cultural distinctiveness, but it does require that the members of a given ethnic group believe in their cultural distinctiveness." So, as Barth emphasizes, Madhesi boundaries should be understood in terms of people's cognitive proclivities which are underpinned by and are expressed through their social practice (Cohen, 2000) in the course of interactions with the "others."

\section{The expanding and contracting nature of Madhesi boundary}

Ethnic boundaries are the outcome of the classificatory struggles and negotiations between actors situated in a social field (Wimmer, 2008). Along with reinforcing shared culture, as actors, Madhesis have pursued different strategies to shift the membership to include or exclude other groups in their perceived boundaries. Madhesi boundary has been built on the subjective view points of Madhesis. The making and maintenance of Madhesi boundary sometimes seems flexible and other times rigid depending on the contexts in which they interact with the "others". At Some points in time (even in the course of Madhesi movement) it was stated in Birganj as elsewhere in the Tarai-Madhes that 'MadhesiPahadibhai-bhai ${ }^{24}$, koi chhaina parai' (Madhesis and Pahadis are brothers, no one is alien).

\footnotetext{
${ }^{24}$ See Rai (2017) for understanding how Limbu and Dhimals, the hill and Tarai indigenous groups, who are considered to be distinct and different, are kin groups who possess a shared myth of common spatialgenealogical history of origin. He discusses how Dhimal make, critique and redefine the idiom of kinship the perceived daju - bhai relations between Dhimal and Limbu through concrete cultural politics such as history writing, and place making, and through a collective political mobilization for the establishment of Limbuwan in Nepal.
} 
Citing such a slogan implies as if no boundary exists between Madhesi and Pahadi. Such a sense breeds cordial relationship and tolerance among the people of Pahadi and Madhesi origins. Such a perceived relation of bhai - bhai, brotherhood between Pahadi and Madhesi has been rooted on a myth that both were descended from common ancestors (who could be Aryan) in a distant past that cannot be located precisely. Many individuals, irrespective of their origin, claim that Birganj is such a place where two communities - Pahadi and Madhesi - have been co-existing with mutual social interactions without losing own cultural rootedness but by accommodating each other's culture to a greater extent. Birganj witnessed many sadbhab (solidarity) rallies collectively organized by both Pahadi and Madhesi people amidst the increasing antagonism and violent clashes between two communities. At such times the 'differences' were overlooked and both the communities perceived themselves as same citizens grounding on the sense of humanity. It shows that Madhesis do not want always to be distant from "others," rather they want to be tied with them with harmony and coevality.

This reflects that delimiting the membership to the cultural or territorial boundary sometimes seems blurred. By emphasizing civilizational commonalities and evoking the universal moral qualities and membership in "the human family" (Wimmer, 2008, p. 989), Madhesis' behaviors and actions sometimes blur the boundaries between Madhesi and Pahadi. An elderly Madhesi individual representing Madhesi upper caste whom I met in the premises of Gahawamai temple of Birganj narrated with me, "Except Pahadi janjati groups, both Pahadi and Madhesi are the followers of Hinduism and both are organized into a caste structure. Indeed, both belong to the same civilization.” Ideally, for having a common religious faith, distinction between two communities has been avoided. Such a boundary blurring attempts to emphasize that there should be equality but not difference between Madhesi and Pahadi.

Ethnic boundaries do not isolate groups entirely from each other; rather, there is a continuous flow of information, interaction, exchange and sometimes even people across them (Eriksen, 2010, p. 46-47). As experienced by some of my research participants in Birganj, the gradually increasing marital relationship between Pahadi and Madhesi people (see Basnet and Jha, 2019) as well as rapidly increasing sense of neighborhood between the two groups through migration has made the cultural boundaries narrow. There are not only the Pahadi people settling in the Tarai villages and towns but also the Madhesi people are increasingly settling in the cities located at Pahad such as Kathmandu. This implies that at certain circumstances, as Wimmer (2008, p. 983) notes, "ethnic boundaries do not divide a population along obvious cultural lines but unite individuals who follow quite heterogeneous cultural practices". 
Yet, boundaries between Pahadi and Madhesi communities have been maintained at another point of time mostly when Madhesi people have been indulged in identity struggles raising the issues of equality, dignity, inclusion and representation in national mainstream, people are divided along Pahadi - Madhesi lines and their relationship have gone antagonistic. Sharply defined boundary was constructed by Madhesi people based on their cultural distinction to exclude the membership of Pahadi people from imagined Madhesi community, a subjectively felt sense of belonging to the Madhesi community. In this connection, Madhesis campaigned for Pahadi hatao (Pahadis out of plains) in some places in the Tarai ${ }^{25}$. Madhesi people claim that when their existence and identity get threats from their counterparts - Pahadis for the worth of their culture, it seems obvious to create rhetoric from the vantage point of political and economic perspectives. At this point, as Barth (1969, p. 15-16) argues, "Ethnic groups only persist as significant units if they imply marked difference in behavior, i.e. persisting cultural difference" seems applicable. When Madhesis distinguish themselves as different from others, especially Pahadis, and treat those differently Madhesi social and symbolic boundaries have been maintained.

Many Madhesi individuals confessed that during Madhesi movement many Pahadi origin people managed to escape from Tarai-Madhes, mostly from the plain area where they were minority, to seek the refuge from their kin folks. According to a local political leader, two factors contributed for it. First, Pahadi people felt insecure as people different from them had waged intense protests and resentment against government led by their stock. Second, in some places Pahadi people were made target especially by Madhesi armed groups violently to force them to leave the plain through chanting slogans such as Pahadi murdabad, 'Pahadi, get back to the Pahad' or 'Pahadi, leave the Madhes', and the like. In some places along the east-west highway where the Pahadis form the majority, they did the same to the minority Madhesis.

Yet, my research participants stated that except those who had self-desires to flee, no Pahadi people were forced to leave their settlement from around Birganj; Pahadi people felt insecurity not from the common Madhesi people but from the armed Madhesi groups who made Pahadis a target for extortion. They acknowledged that many Pahadi people living in and around Birganj since long had expressed their aikyabaddhata, goodwill and solidarity to the Madhesi issues raised during Madhesi movements. However, a Madhesi activist noted:

\footnotetext{
${ }^{25}$ Dahal (1992) reports that some Tarai leaders, particularly those representing the Hindu caste groups in the Sadhbhavana Party, have started a PahadiaHatao campaign to physically remove the hill peoples from the plains.
} 
Those Pahadis who expressed their solidarity to the Madhesi movement too were like "others." During Madhesi struggles Pahadis instinctively favored the suppressive actions of government against Madhesis in tacit form. Madhesis were concerned for their own freedom as they were trapped in a complex net of cultural, economic and political discrimination and oppression from the state policies. Some Pahadis' support to Madhesis' effort for identity struggle was sympathetic act but their inherent attachment was not to the Madhesi community and its issues. Pahadi people cannot truly feel or grasp exactly the sufferings or grievances and humiliation theMadhesis have felt since long.

This statement signals that Pahadis have been distanced from the issues of Madhesi identity struggle. Even though, many Pahadi people share the same territory as long residents as Madhesis and might have accommodated Madhesi culture to some extent, they have been excluded from the membership of Madhesi political and socio-cultural boundary. The claim of hill migrants as Madhesis for living in Madhes for long has been denied by the Madhesis on the ground of origin, language and culture especially in the realm of political representation.

Obviously, the boundaries that the Madhesis tend to make seem politically salient. The politics of inclusion-exclusion escalates between the groups for tapping the political opportunities. When boundaries are salient, political alliances are more likely to be formed between coethnics than between individuals on opposite sides of a boundary (Wimmer, 2008). The Hindu caste groups of the Tarai attempted to include Muslims and Tarai ethnic groups such as Tharu in the Madhesi category. An attempt of Madhesization of non-Pahadi people including Tarai ethnic groups such as Tharus and religious group such as Muslims was a strategy of boundary expansion. Madhesis' claim was that Tharu share the same territory for settlement, posses some sort of cultural commonality and have been exploited and discriminated by the state like Madhesis. It could be a strategy to broaden the bases of Madhesi identity. That is, Madhesi leaders and elites had deployed strategies to produce common-sense views regarding belonging and identity. To some extent phenotypical similarities between caste groups and Tharu and their common grievances of disrespect and humiliation from Pahadi people brought them together. Likewise, the shared territorial history, language and lifestyle have prevailed over the identity of Tarai Muslims and in fact contributed to their plurality of identity of being Madhesi and Muslim at the same time (Dastider, 2013). At one level, their common Madhesi identity make both Hindus and Muslims share the discrimination meted out to them by the politically dominant hill elites, pertaining to discrimination in citizenship, under-representation in government services, and towards the language and culture of Tarai...When it comes to the Hill-Tarai divide, 
Madhesi Muslims and Hindus find themselves identified with the Tarai and thus possess a joint Madhesi identity (Dastider, 2007, p. 134-135).

However, the inclusion and exclusion of membership to the Madhesi category seems contested even among the non-Pahadi groups. That is, there has been identity contestation among the non-Pahadi groups - especially among Madhesi Hindu caste groups and Tharu who claim themselves indigenous people of the Tarai ${ }^{26}$. During the first Madhes movement of 2007, Tharu expressed their solidarity and participated in it in large numbers (ACHR, 2009). But shortly, many Tharu leaders realized that Madhesis were trying to impose their own hegemonic identity, without respecting the distinct Tharu identity (ACHR, 2009). Madhesis succeeded to subsume Tharu under Madhesi category while making amendment in interim constitution of 2007. But, Tharu agitation of 2009 aired separate Tharuhat province and established Tharu as a separate category (Pandey, 2017).

Muslims too equally participated in Madhes uprising and some of them became martyrs too (Upreti et al, 2013). However, in the changing political context, Muslims do not want to be called just as Madhesis and they are demanding their separate identity (Upreti et al, 2013). Not only Muslims keep them apart from Madhesi category themselves but also the caste Hindus see Muslims as "others". One of my research participants representing the Madhesi middle caste group shared with me:

Muslims have been grabbing the political opportunities in the name of Madhesis. At the local to regional and even to national level, many Muslims have occupied the political positions from the quota of Madhesis. They have been reaping the benefits in government services. Muslims should have been out of Madhesi category as they are distinct from Madhesis in terms of religious faith. Indeed, they have been doubly benefitted grasping the quotas of Madhesis and religious minority group.

This is indicative of that at certain points, especially in the matters of political representation and economic opportunities, Madhesi boundary seems narrow excluding the membership of some closer groups. Moreover, within the Madhesis too different caste groups tend to construct boundary in certain aspects of their socio-cultural interaction.

\footnotetext{
${ }^{26}$ ACHR (2009, p. 11) has reported that Madhesi parties claim that Tharus are Madhesis since they live in Madhes, have similar cultural practices as Madhesi castes, and both have been exploited by the state but Tharu activists see Madhesi upper castes as exploiters as well, who came over from across the border and took over the land. TheTharu movement led the fractured ties between Madhesis and Tharus on the ground. Guneratne (2009, p. xxiii) notes that although some Tharus are active in Madhesi politics, and a few have risen to positions of influence in the Madhesi movement, Tharus in general do not see themselves as Madhesis, and actively resent the configuration of the Tarai as Madhes. Pandey (2017) has discussed Tharu contestation of Madhesi identity which was manifest in the Tharu agitation of 2009.
} 
Madhesis of different caste groups confessed that lower Madhesi castes have been still secluded from higher caste in most of the ritual affairs. Caste groups have their specifically restrictive ritual domains. Likewise, there has been a clear cut demarcation between rich and poor in terms of their standard of living and access to resources and power. However, such a boundary that separates Madhesis in terms of membership to the caste and the class has not divided Madhesis at the macro-level. Less emphasizing their micro-level boundary maintenance activities, Madhesis are found united at the macro-level at least while interacting with the Pahadi community and the state. This implies that at wider level, boundary making process of Madhesi people seems to be depending on their position on the hierarchies in terms of both political power and culture at national levels. They want "others," especially the Pahadis recognize them politically and culturally. On the other hand, boundaries have been maintained among diverse groups of Madhesis through their actions and behaviors accompanied with their membership to particular caste and class.

As evident above, Madhesi ethnicity seems malleable and impermanent as it meanders situationally. It can be argued that depending on the circumstances Madhesis have seek to establish a new boundary by expanding the range of people included and also have aimed to reducing the range of the included by contracting boundaries ${ }^{27}$. Referring to a shared sense of discrimination from the state and Pahadi people, Madhesis, Tharu and Muslims groups have developed a sense of anti-hill solidarity. As Lawoti (2005, p. 97) argues that the racist attitudes towards all the Madhesi communities from the "upper-caste" Brahmin to the Dalit and from indigenous peoples to the Muslims have united the Madhesi community despite considerable contradictions within them.

\section{Claim of ethno-territoriality in the maintenance of Madhesi Boundary}

The chief editor of a Birganj based daily newspaper stated:

There are several instances in which Pahade leaders practically regarded the Madhesi community as their political supporters and vote bank. Several times Madhesis have elected Pahade leaders of so called mainstream political parties from different electoral constituencies of the Tarai. However, Pahade leaders' niyat (inherent attitude) hadn ever been positive towards Madhesis. Madhesis' votes meant a lot for them for competing to hold political power. But, Madhesis' genuine demands are always perceived as anti-national. Pahade leaders could not become the true representatives of the Madhesi people. Likewise, Pahade immigrants with the aid of different state policies such as land reform policy, resettlement policy and

\footnotetext{
${ }^{27}$ See Wimmer (2008, p. 986- 989) for elementary strategies of ethnic boundary making.
} 
citizenship policy always made efforts to displace the Madhesi people from their land or to keep them in the subservient position who could never challenge the Pahadis' privileges. So, Madhesis want a Madhes province that would truly ensure their participation and representation in their own affairs. They believe that autonomous Madhes province provides them strength confidence and self-esteem in socio-political matters.

Likewise, a local level leader of the then Rastriya Janata Party put Madhesis' ethnoterritorial claim over the Tarai in this way:

There has been a close connection between Madhesis' life and the ecology of the Tarai. Madhesis along with other Tarai people such as Tharu made the Tarai land productive through their labour. Undermining such facts, the centralized and hegemonic state always misrecognized and disregarded the Madhesi identity and treated Madhesi people as Indians. The rulers always denied the equal access of Madhesi people on political power and economy even in their own region. For ensuring the representation and inclusion of Madhesis in social and political institutions and for making them owner of the things they posses autonomy of the Tarai is the only solution.

These narratives imply that though theMadhesi boundary is a social boundary, it has territorial counterpart. That is, Madhesis believe that their identity is largely shaped not only by their distinct culture but also by the territorial dimension. Territory as perceived here is not merely the physical space but is imbued with culture, politics and economy. The Tarai, particularly the central Tarai is a place where settlement of Madhesi people seems highly concentrated and where Madhesi culture seems dominant. Escobar (2001, p. 140) argues that place reflects the experience of particular location with some measure of groundedness (however, unstable), sense of boundaries (however, permeable), and connection to everyday life, even if its identity is constructed, traversed by power, and never fixed. Peoples' sense of place and experiences of places are equally influenced and shaped by larger political-economic contexts and power relations (as cited in Rai, 2013, p. 279). Ethno-territoriality as perceived by Madhesis seems to be the fusion of territoriality with ethnic claims. From the perspective of Madhesis, ethno-territoriality serves "as a social and political project the goal of which is to establish an explicitly spatial basis for claims involving ethnic identity, cultural rights, and political authority by identifying and constructing certain places or territories as belonging to or appropriate for certain ethnoregional categories of people and practice, and by extension displacing other categories" (Moore, 2015, p. 95).

Territorial recognition is an important means of recognizing a community's genuine attachment to place (Shneiderman and Tillin, 2015). But, in the understanding of Madhesis, 
the state has always undermined their belonging and attachment to the land they inhabit. Peoples' sense of attachment to their lived places can be a powerful motivation driving the political actions that people undertake to defend and reclaim their places (as cited in Rai, 2013, p. 280). The longstanding bias against Madhes and Madhesis seem to be one of the crucial factors for seeking autonomy. Madhesis perceived that the disproportionate distribution of economic resources that are prevailing in the Tarai in favour of the Pahadi people obstructed their economic wellbeing. For redressing their economic grievances, Madhesis have sought political autonomy.

Madhesis' ethno-territorial claim has to be seen in relation to the historical and structural contexts and their agency in response to such contexts. The defense of Tarai territory and Madhesi identity has become political projects in the early1950s following the collapse of Rana regime. Tarai Congress attempted to establish Madhesi identity as ethno-political identity by advocating establishment of 'an autonomous Terai state, recognition of Hindi as a state language, and adequate employment of Tarai people in the Nepal civil service' (Gaige, 2009, p. 109). Raghunath Thakur established Madhes Mukti Andolan in 1956 to oppose and fight against discrimination and exploitation of Madhesis and demanded right of self-governance in Tarai (Goait, 2007).Nepal Sadbhavana Party, a Tarai-Madhesh based regional party established in the 1990 demanded federalism, reservation and distribution of citizenship certificates along with the key demands of Nepal Tarai Congress (Hachhethu, 2009).The formation of Madhesi Rastriaya Mukti Morcha, a sister organization of Maoist party in 2000 encouraged militant Madhesi nationalism raising the issues of inclusion, federalism with right to self-determination, language and culture rights, and reservation that enabled to mobilize the grassroots Madhesi population (Hachhethu, 2009).

Since the Panchayat regime, Madhesis see the East-West highway that runs along the lap of Chure range as a boundary that compartmentalizes Pahad and Madhes. Singh (2008) argues that the construction of East-West high way and the government's encouragement of the settlement of hill people along the highway weakened the Madhesis' economic, political and cultural dominance in the Tarai. As no border towns and densely clustered Madhesi settlements fall in the national highway, they witnessed economic recession ${ }^{28}$. Rather than integrating Madhes with the Pahad, East-West highway has divided both the communities which become evident especially in the political movements. This in turn has created

\footnotetext{
${ }^{28}$ In an article "Undeclared Borders” published in Kathmandu Post daily in 8 August, 2017, Kalpana Jha has shed light on how road, especially East-West highway produced economic recession on once vibrant towns of Tarai taking reference of Rajbiraj. She argues that East-West highway not only created a territorial line between Pahad and Madhes, it also compartmentalized the entire Tarai.
} 
consciousness of boundary maintenance. Madhesis have understood that Pahadi community has regarded the East-West highway as bulwark that protects Pahadi from the intervention of Madhesi culture and politics.

There were several works at play to make ethno-territorial claim over the Tarai-Madhes during and after the 2007 Madhes uprising. Replacing Nepal sarkar by Madhessarkar especially in the sign boards of government organizations had become a popular strategy of Madhesi protesters to publicly express their desire of self-governance. At the time of field work in March 2018, I saw Madhessarkar written in the sign board of some offices and on the street walls. When I asked my research participants what they imagined about the Madhes sarkar, their common answer was the active involvement of Madhesis in the governing bodies. For them, sarkar meant not only the executive but also legislative and judiciary that can actually satisfy the needs, demands and aspirations of Madhesi people.

Madhesis' dissatisfaction and resentment against the demarcation of provincial boundaries clearly exhibited the politics of boundary making in terms of territory. One of the central demands of Madhesis in the course of their successive movements was identification with and assertion of authority over the Tarai-Madhes which is ecologically, linguistically and culturally distinct from the mid-hills of Nepal. The slogan of Whole Madhes, One Pradesh (during the regime of first constituent assembly) and 'down with hill administration' clearly reflected the Madhesis'ethno-territorial claim. In Escobar's (2001) words, this was a placebased strategy that relies on the attachment to territory and culture. It was perceived that such a slogan was used as a tactical strategy to bargain with government by Madhesipolitical parties and leaders to restructure the national power equation thus ensuring their proportional representation.As the strength of the demand of Whole Madhes, One Pradesh went on waning for being practically unfeasible because of the complex structure and relations inherent in Tarai-Madhes ${ }^{29}$, Madhesis' demanded at least two provinces in the Tarai prior to the promulgation of new constitution. However, the new constitution of 2015 ensured the incorporation of eight districts of the central Tarai where predominantly Madhesi people live - Parsa, Bara, Rautahat, Sarlahai, Saptari, Siraha, Mahottari and Dhanusha in the Province 2.

Madhesis' urge for identification with and political authority over their perceived homeland, the Tarai, especially the central Tarai seems to be based on the belief that Tarai territory was laboriously constructed through the daily cultural and economic practices of them. Madhesi ethnic consciousness, in part, has aroused from the geopolitical reality of the

\footnotetext{
${ }^{29}$ The rising dissension within and among Madhes based political parties and the discontents of Tarai indigenous groups particularly of Tharu led to a weakening of the slogan.
} 
Tarai. Being conscious of the fact that Tarai is the 'bread basket' of Nepal that possesses the most fertile agricultural land and a hub for industries and trade, Madhesis have sought for increasing access and right on the economy of Tarai. For this end, they have provoked ethno-regional identity. Thus, it becomes evident that Madhesis' demand of autonomy in the Tarai was apparently political and economic.

\section{Conclusion}

The process of constructing boundaries is an ongoing one in which boundaries, rather than being rigidly constructed, remain fluid and flexible (Fisher, 2001). However, in the Madhesis case the fact is that in asserting dignity and recognition and recovery from exclusion through demands for egalitarian representation, identity boundaries have hardened (Sijapati, 2013).As Wilmsen(1996) has noted, Madhesi ethnicity appears to come into being most frequently in just such instances when individuals are persuaded of a need to confirm a collective sense of identity in the face of threatening economic, political or other forces.That is, ethnic identities tend to attain their greatest importance in situations of flux, change, resource competition and threats against ‘boundaries' (Eriksen, 2010, p. 120).

Madhesi boundaries have been constructed in response to economic, cultural and political opportunities and constraints prevailing in Nepal over time. They have been strategically constructing the boundaries: at different times and in different contexts, they expanded or limited the domain to include the people in the Madhesi category. The Madhesi people have developed different forms of behaviors vis-a-vis different categories of 'others'. For example, the Madhesi perceive Tharu and Muslims inhabiting in Tarai as 'like themselves' but the Pahadis inhabiting in the same region are perceived as 'extremely different from them'. When they attempted to link themselves with other people using social categories other than cultural or linguistic affiliation, it sometimes made Madhesi identity contentious. Whatever else, Madhesi ethnic distinctions and boundaries have become sharper when interethnic interactions become intense. Thus, as Cohen (1998) asserts, Madhesi boundary is essentially a matter of consciousness and of experience, rather than of fact and law. Madhesi ethnicity has to be conceptualized "not as substance or thing or entity, or organism or collective individuals... but rather in relational, processual, dynamic, eventful and disaggregated terms” (Brubaker, 2004, p. 11).

Madhesi case explicitly demonstrates, as Guneratne (1998, p. 770) argues, "Although ethnicity presents itself to us as a cultural phenomenon, its genesis and development must be sought in the socioeconomic conditions... Identities are formed and transformed, and ethnic boundaries are contracted and expanded as the circumstances in which individuals and societies find themselves change." Madhesi people seem to have used cultural differences and ethnic boundaries as a resourceto achieve specific aims versus competing 
actors - especially the Pahadis.Thus, the ethnicization of Madhesis has to be seen as ongoing political, social, cultural and psychological process in the changing circumstances.

\section{References}

Asian Center for Human Rights (ACHR). (2009). Madhes: Challenges and opportunities for a stable Nepal. Briefing papers on Nepal, Issue no. 3.

Barth, F. (1969). Introduction. In F. Barth (Ed.), Ethnic groups and boundaries: The social organization of culture difference. George Allen and Unwin.

Barth, F. (1994). Enduring and emerging issues in the analysis of ethnicity. In H. Vermeulen\& C. Govers (Eds.), Anthropology of ethnicity: Beyond ethnic groups and boundaries. Het Spinhuis.

Barth, F. (2000). Boundaries and connections. In A. P. Cohen (Ed.) Signifying identities: Anthropological perspectives on boundaries and values. Routledge.

Basnet, C and Jha, R. (2019). Crossing the caste and ethnic boundaries: Love and intermarriage between Madhesi men and Pahadi women in southern Nepal. South Asia Multidisciplinary Academic Journal

Bhattarai, H. P. (2000). Identities in the making: Cultural pluralism and the politics of imagined communities in the lowlands of Nepal. An unpublished dissertation submitted to department of social anthropology, university of Bergen.

Bista, D. B. (1996). People of Nepal. RatnaPustakBhandar.

Brubaker, R. (2004). Ethnicity without groups. Harvard University Press.

Cohen, A. P. (1985). The symbolic construction of community. Routledge.

Cohen, A. P. (1998). Boundaries and boundary consciousness: Politicizing cultural identity. In M. Anderson and E. Bort (Eds.) The Frontiers of Europe. Pinter.

Cohen, A. P. (2000). Introduction: Discrimination relations - identity, boundary and authenticity. In A. P. Cohen (Ed.) Signifying identities: Anthropological perspectives on boundaries and values. Routledge.

Dahal, D. R. (1992). Grasping the Tarai identity. Himal, vol 5.

Dahal, D. R. (2008). The 'Madhesi' people: Issues and challenges of democracy in the Nepal Tarai. In D. Gellner\& K. Hachhethu (Eds.), Local Democracy in South Asia: Microprocesses of Democratization in Nepal and its Neighbors. Sage Publications.

Dastider, M. (2007). Understanding Nepal: Muslims in a plural society. Har-Anand Publications.

Dastider, M. (2013). Refusing to choose: the Muslim Madhesi and the coexistence of religious and regional identity in Nepal's Tarai. In M. Lawati and S. Hangen (Eds.), Nationalism and ethnic conflict in Nepal: Identities and mobilization after 1990. Routledge.

Eriksen, T. H. (2010). Ethnicity and nationalism: Anthropological perspectives. Pluto Press.

Escobar, A. (2001). Culture sits in places: Reflections of globalism and subaltern strategies of localization. Political Geography, 20(2), 139 - 174.

Fisher, W. (2001). Fluidboundaries: Forming and transforming Thakali identity in Nepal. Columbia University Press.

Gautam, B. (Ed.). (2008). Madhes Bidrohako Nalibeli (Details of Madhesi Revolt). Martin Chautari. Gaige, F. H. (2009 [1975]). Regionalism and national unity in Nepal. Himal Books. 
Gellner, D. N., Pfaff-Czarnecka, J., and Whelpton, J. (Eds.). (2008) [1997]. Nationalism and ethnicity in Nepal. Kathmandu: Vajra Publications.

Goait, J. K. (2007). History of Tarai in Nepal: Nepalese rule in Tarai. https://madhesi.wordpress.com/2007/04/04/history-of-terai-in-nepal/

Guneratne, A. (1998). Modernization, the state, and the construction of a Tharu identity in Nepal. The Journal of Asian Studies, 57(3), 749-773.

Guneratne, A. (2002). Many tongues, one people: The making of Tharu identity in Nepal. Cornell University Press.

Hachhethu, K. (2007). Madhesi nationalism and structuring Nepali state. A paper presented at an international seminar on"Constitutionalism and Diversity in Nepal" Organized by CNAS, TUin collaboration with MIDEA Project and ESP-Nepal, 22-24 August 2007, Kathmandu, Nepal.

Hachhethu, K. (2009). Research Briefs: State and Ethnicity. Social Inclusion Research Fund.

Hangen, S. (2010). The rise of ethnic politics in Nepal: Democracy in the margin. Routledge.

Holmberg, D. 1996 [1989]. Order in paradox: Myth, ritual, and exchange among Nepal's Tamang. MotilalBanarsidass.

Hyome, K. (2006). Madhesi pratiko bibhed ra samanta aandolan (Discrimination against Madhesi and the movement of equality). In B. Thapa\& M. Mainali (Eds.) Madhes: Samasya ra sambhavana. Social Science Baha.

Jha, H. B. (2017 [1993]). The Terai community and national integration in Nepal. Adroit Publishers.

Jha, K. (2017). Undeclared borders. Kathmandu Post daily, August 8, 2017.

Jha, M. (2016). Identifying with identity. Nepali Times, 8-14 July, 2016.

Lawoti, M. (2005). Towards a democratic Nepal: Inclusive political institutions for a multicultural society. Sage Publications.

Levine, N. E. (1987). Caste, state and ethnic boundaries in Nepal. Journal of Asian studies, 46(1), $71-87$.

Mathema, K. B. (2011). Madhesi uprising: The resurgence of ethnicity. Mandala Book Point.

Moore, A. (2015). Ethnoterritoriality and ethnic conflict. Geographical Review, 106(1), 92 - 108.

Pandey, K. (2017). Politicizing ethnicity: Tharu contestation of Madhesi identity in Nepal's Tarai. The South Asianist, 5(1), 304-322.

Rai, J. (2013). Activism as a moral practice: Cultural politics, place making and indigenous movements in Nepal. An unpublished dissertation submitted to the University of Michigan, USA.

Rai, J. (2017). Dhimal-Limbu dajubhai: Inter-ethnic kinship, place making and indigenous activism in eastern Nepal. In L. P. Upreti, B. Pokharel and S. Dhakal (Eds.), Kinship studies in Nepali anthropology. Central Department of Anthropology, TU.

Sah, R. M. (2017). The middle country: The traverse of Madhes through war, colonization and aid dependent racist state. Adroit Publishers.

Shah, S.G. (2006). Social inclusion of Madhesi community in nation building. Civil Society Forum Workshop for Research programme on social inclusion and nation building in Nepal, Organized by Social Inclusion Research Fund (June, 2006). 
Shneiderman, S and Tillin, L. (2015). Restructuring states, restructuring ethnicity: Looking across disciplinary boundaries at federal futures in India and Nepal. Modern Asian Studies, 49(1), 1 39.

Shneiderman, S. (2012). Restructuring the state, restructuring ethnicity: Situating Nepal in contemporary social scientific debates. In C. Mishra and O. Gurung (Eds.), Ethnicity and federalism in Nepal. Kathmandu: Central Department of Sociology/ Anthropology, TU.

Sijapati, B. (2013). In Pursuit of recognition: Regionalism, Madhesi identity and the Madhesandolan. In M. Lawoti\& S. Hangen (Eds.), Nationalism and Ethnic Conflict in Nepal: Identities and Mobilization after 1990. Routledge.

Singh, A. K. (2008). The restructuring of the Nepali state: The Madhese perspective. In L. Baral (Ed.), New frontiers of restructuring of state. Adroit Publishers.

Upreti, B. R., Paudel, S. B., \& Ghimire, S. (2013). Ignored or ill-represented? The grievance of Terai-Madhes conflict in Nepal. New Delhi: Adroit Publishers.

Wilmsen, E. N. (1996). Premises of power in ethnic politics. In E. N. Wilmsen and P. MacAllister (Eds.), The politics of difference: Ethnic premises in a world of power. The University of Chicago Press.

Wimmer, A. (2008). The making and unmaking of ethnic boundaries: A multilevel process theory. American Journal of Sociology, 113(4), 970-1022.

Yadav, R. (2011). On being Madhesi. In A. Guneratne (Ed.) The Tarai: History, society, environment. Himal Books. 